\title{
Karakteristik Sosial Ekonomi Petani Miskin dalam Pengelolaan Usaha Mikro "Tourism Souvenir Goods"
}

\author{
DUMASARI, ${ }^{1}$ WATEMIN 2 \\ 1,2 Agribisnis, Fakultas Pertanian, Universitas Muhammadiyah Purwokerto, Jl. Raya Dukuh Waluh, \\ Purwokerta. \\ email: ${ }^{1}$ dumasarilumongga@yahoo.com; 2 watemyn@umpac.id
}

\begin{abstract}
This article aims to consider the socio economic characteristics of poor peasant and profile of micro enterprises tourism souvenir goods made from agricultural waste which is managed in the countryside. The research takes place in the rural of Baturaden and Cilongok Tourism Area, Banyumas Regency, Central Java Province. The research method was a descriptive case study with a qualitative and quantitative approach. The research results revealed that poor peasant have certain socio economic characteristics in managing their micro enterprises tourism souvenir goods in the rural of Baturaden and the Cilongok Tourism Area. These certain criterias are they have the power to encourage and motivate potential influence and spirit in managing their micro enterprises. The profile of micro enterprises shows the similarities and differences in indicators observed. Poor peasant need some real efforts to increase self reliance and entrepreneurship skills in the development of their own micro enterpreses at rural area
\end{abstract}

Keywords: socio economic characteristics, poor peasant, micro enterpreses

\begin{abstract}
Abstrak. Artikel ini bertujuan mengkaji karakteristik sosial ekonomi petani dan profil usaha mikro tourism souvenir goods berbahan limbah hasil pertanian yang dikelolanya di pedesaan. Lokasi penelitian ditetapkan secara purposive area di pedesaan Kawasan Wisata Baturaden dan Kawasan Wisata Cilongok, Kabupaten Banyumas, Propinsi Jawa Tengah. Metode yang digunakan pada penelitian ialah studi kasus deskriptif dengan pendekatan kualitatif kuantitatif. Berdasarkan hasil penelitian diketahui bahwa petani miskin memiliki karakteristik sosial ekonomi tertentu dalam mengelola usaha mikro tourism suvenir goods di pedesaan Kawasan Wisata Baturaden dan Kawasan Wisata Cilongok. Beberapa kriteria karakteristik sosial ekonomi petani miskin mempunyai kekuatan pengaruh mendorong dan memotivasi potensi dan semangat petani miskin dalam mengelola usaha mikro. Profil usaha mikro tourism souvenir goods yang dikelola petani miskin menunjukkan adanya persamaan dan perbedaan dalam beberapa indikator yang diamati. Petani miskin membutuhkan upaya riil untuk peningkatan kemandirian dan kemampuan kewirausahaan dalam mengembangkan usaha mikro produk souvenir untuk pasar wisata di pedesaan.
\end{abstract}

Kata kunci: karakteristik sosial ekonomi, petani miskin, usaha mikro

\section{Pendahuluan}

Pemberdayaan petani miskin di pedesaan tetap penting dilakukan secara intensif. Hal ini didasarkan fakta sosial yang menunjukkan kualitas sumberdaya manusia yang dimiliki rumahtangga petani miskin relatif rendah ditinjau dari aspek produktivitas, pendidikan, kemandirian, kewirausahaan, melek usaha dan kreativitas. Berbagai upaya pemberdayaan terus dilakukan pemerintah bersama pihak lain untuk mengembangkan kemampuan dan kemandirian petani miskin dalam memanfaatkan potensi sumberdaya alam lokal di pedesaan. Hanya saja hasil yang dicapai seringkali belum optimal terbukti mayoritas (> 50\%) dari total jumlah penduduk miskin di Indonesia terdiri dari petani gurem dan nelayan kecil.

Daya kreativitas petani miskin yang rendah dalam menekuni berbagai jenis pekerjaan produktif di sektor pertanian dan non pertanian sebenarnya pantas dimaklumi karena akses informasi terhadap ragam inovasi terutama tentang pemanfaatan teknologi modifikasi produk masih minim. Sebagai konsekuensi, petani miskin belum mampu mengolah sumberdaya alam di sekitarnya menjadi 
beragam produk bernilai ekonomi.

Aneka jenis limbah hasil pertanian termasuk bagian dari sumberdaya alam di pedesaan, yang belum terolah petani miskin menjadi ragam produk bernilai tambah. Selama ini, aneka jenis limbah hasil pertanian cenderung masih dibiarkan terbengkelai hingga rawan menjadi polutan pencemar lingkungan. Padahal jumlah aneka jenis limbah hasil pertanian tersebut melimpah tertumpuk dan terserak di berbagai tempat lingkungan sekitar desa. Persoalan ini perlu segera diperhatikan secara serius karena mengingat petani miskin sesungguhnya memiliki potensi dalam memanfaatkan aneka jenis limbah hasil pertanian sebagai bahan baku beragam produk seperti souvenir tourism goods. Dengan mengelola usaha mikro tourism souvenir goods, petani miskin berarti mampu mengembangkan diversifikasi nafkah yang nantinya memberikan tambahan berharga bagi pendapatan keluarga.

Berdasarkan hasil penelitian terdahulu di pedesaan Kabupaten Banyumas yang dilakukan oleh Dumasari, et al., (2007) diketahui bahwa usaha mikro tourism souvenir goods berbahan limbah hasil pertanian yang dikelola wanita tani ternyata dapat meningkatkan pendapatan rumahtangga petani miskin $100-200 \%$ setiap bulan. Hanya saja, teknik pengelolaan usaha mikro tourism souvenir goods yang dilakukan petani miskin belum kreatif dan inovatif. Proses pengolahan yang dilakukan bersifat tradisional. Desain produk yang dihasilkan kurang variatif. Tidak jarang, petani miskin mengolah produk baru setengah jadi langsung dijual ke pedagang pengumpul. Harga tourism souvenir goods hasil produksi petani miskin jadi jauh lebih rendah dibanding yang berlaku di pasar.

Permasalahan tersebut dalam waktu relatif tidak lama rawan melemahkan posisi tawar dan pada akhirnya merugikan petani miskin. Dengan demikian, tujuan penelitian ini dimaksudkan mengkaji karakteristik sosial dan ekonomi petani dan profil usaha mikro tourism souvenir goods berbahan limbah hasil pertanian yang dikelolanya di pedesaan.

Lokasi penelitian ditetapkan secara purposive area di pedesaan Kawasan Wisata Baturaden dan Kawasan Wisata Cilongok, Kabupaten Banyumas, Provinsi Jawa Tengah. Metode penelitian yang digunakan studi kasus deskriptif dengan kombinasi pendekatan kualitatif dan kuantitatif.

Subjek penelitian mencakup semua petani yang tertarik dan telah mulai mengelola usaha mikro tousris souvenir goods berbahan aneka jenis limbah pertanian yang bertempat tinggal di pedesaan kedua lokasi penelitian terpilih. Subjek informan mencakup petani miskin yang telah mulai mengelola usaha mikro tourism souvenir goods dari limbah hasil pertanian sebagai bentuk realisasi pengembangan diversifikasi nafkah produktif. Informan dipilih secara purposive sampling dengan rincian yang mewakili pedesaan Kawasan Wisata Baturaden sebanyak 14 orang dan dari pedesaan Kawasan Wisata Cilongok sejumlah 12 orang. Jumlah keseluruhan informan yang diwawancarai ialah 26 orang. Adapun responden penelitian ditetapkan dengan teknik simple random sampling. Responden berasal dari kalangan petani miskin, yang menyatakan ketertarikan mengelola usaha mikro tourism souvenir goods untuk mengembangkan diversifikasi nafkah produktif. Dari pedesaan Kawasan Wisata Baturaden ditetapkan sejumlah 14 orang responden. Sementara, dari pedesaan Kawasan Wisata Cilongok dipilih sejumlah 10 orang. Total responden penelitian 24 orang.

Data yang dibutuhkan dalam penelitian mencakup data primer dan data sekunder. Teknik pengumpulan data dilaksanakan melalui wawancara, observasi dan analisis data sekunder. Data kualitatif dianalisis dengan Interactive Model of Analysis (Miles and Huberman, 1991). Teknik analisis ini dilakukan secara interaktif pada proses pengumpulan data, reduksi data, penyajian data dan verifikasi atau penarikan kesimpulan. Keempatnya berlangsung secara bersamaan dalam satu siklus. Hasil analisis data disajikan dalam uraian deskriptif yang sistematis, logis dan saling melengkapi.

\section{Karakteristik Sosial dan Ekonomi}

Pemberdayaan petani miskin di pedesaan merupakan proses yang bersifat dinamis dan fleksibel untuk memperluas pilihan bagi warga dalam memeroleh kesempatan kegiatan produktif. Oleh karenanya, warga petani miskin bukan lagi diposisikan sebagai objek namun juga sekaligus sebagai subjek pengelola atau pelaku pemberdayaan. Keberadaan petani miskin menjadi pertimbangan strategis dalam pencapaian tujuan pokok pemberdayaan mulai dari awal hingga akhir (the ultimate end). Pemberdayaan menjadi suatu proses berkelanjutan yang mencakup sistem sosial masyarakat secara keseluruhan menuju kehidupan lebih baik, lebih manusiawi dan lebih beradab. Pemberdayaan juga perlu disesuaikan dengan karakteristik petani miskin termasuk dari dimensi sosial ekonomi.

Artikel ini mengungkapkan bahwa karakteristik sosial ekonomi menunjukkan kemampuan dan potensi diri petani miskin dalam mengelola usaha produktif tourism souvenir goods. Kemampuan diri yang dimaksud diindikasikan dari beberapa ciri berikut: umur, jenis kelamin, tingkat pendidikan formal, tingkat pendidikan tak formal, dan interaksi sosial. Lebih spesifik lagi, Spencer and Spencer (1993) menyatakan bahwa 
karakteristik mendasar pada diri seseorang dapat menentukan kompetensi dalam mencapai hasil kerja terbaik dan efektif berdasarkan kriteria pada suatu pekerjaan atau kondisi tertentu.

Karakteristik sosial dan ekonomi petani miskin yang mengelola usaha mikro tourism souvenir goods berbahan baku limbah hasil pertanian di pedesaan kedua kawasan wisata yang diteliti memiliki kekhasan tertentu sesuai potensi sumberdaya lokal. Berdasarkan hasil pengamatan terhadap karakteristik sosial petani miskin baik di Baturaden maupun Cilongok diketahui mayoritas $(83 \%)$ berusia produktif. Hanya sedikit yang tergolong berusia tidak produktif (17\%). Petani pengelola usaha mikro tourism souvenir goods sebagian besar (88\%) berjenis kelamin laki-laki. Sedikit sekali (12\%) perempuan yang turut menekuni usaha ini. Pekerjaan mengolah limbah hasil pertanian menjadi beberapa desain dan jenis souvenir yang dipasarkan di kawasan wisata membutuhkan keterampilan dan pengalaman yang telaten. Keikutsertaan perempuan dalam usaha ini terbatas pada proses penyiapan dan pengeringan bahan baku serta pengemasan produk dalam kotak/ kardus atau karung plastik.

Tingkat pendidikan formal petani miskin mengelola usaha mikro tourism souvenir goods ternyata masih relatif rendah (SD dan SMP). Keterbatasan kualitas sumberdaya manusia yang dimiliki petani miskin produsen produk souvenir dari limbah hasil pertanian juga terungkap dari pendidikan tak formal yang masih tergolong rendah. Jarang sekali ada penyuluhan atau pelatihan dari berbagai pihak luar tentang berbagai informasi teknologi pertanian dan pengelolaan usaha mikro berbasis kewirausahaan yang diikuti petani miskin baik di Baturaden maupun Cilongok.

Sisi karakteristik sosial lain yang diteliti menunjukkan bahwa interaksi sosial antara petani pengrajin dengan sesama warga desa dan petani pengrajin dengan pedagang pengumpul souvenir relatif tinggi. Pertemuan antara petani pengrajin dengan warga desa berlangsung dalam berbagai acara baik rutin maupun tidak rutin. Interaksi sosial antara petani pengrajin dengan pedagang pengumpul berlangsung efektif, karena minimal sekali seminggu terjadi pertemuan untuk pemesanan sekaligus transaksi pembelian dan pembayaran produk tourism souvenir goods. Sebaliknya, interaksi sosial antara petani pengrajin dengan penyuluh pertanian cenderung rendah karena keduanya jarang bertemu untuk kepentingan pengembangan pembangunan pertanian.

Pengalaman petani pengrajin dalam usahatani rata-rata $>5$ tahun. Sementara, pengalaman mengelola usaha mikro tourism souvenir good lebih rendah karena baru berkisar 2-4 tahun. Penjelasan karakteristik sosial petani miskin di Kawasan Wisata Baturaden dan Kawasan Wisata Cilongok secara rinci tertera pada Gambar 1.

Karakteristik ekonomi petani miskin yang diwawancarai dalam penelitian ini menunjukkan kondisi yang diwarnai ketidakpastian dalam memperoleh pendapatan dari usahatani untuk memenuhi kebutuhan keluarga sehari-hari. Masalah keterdesakan ekonomi yang dihadapi

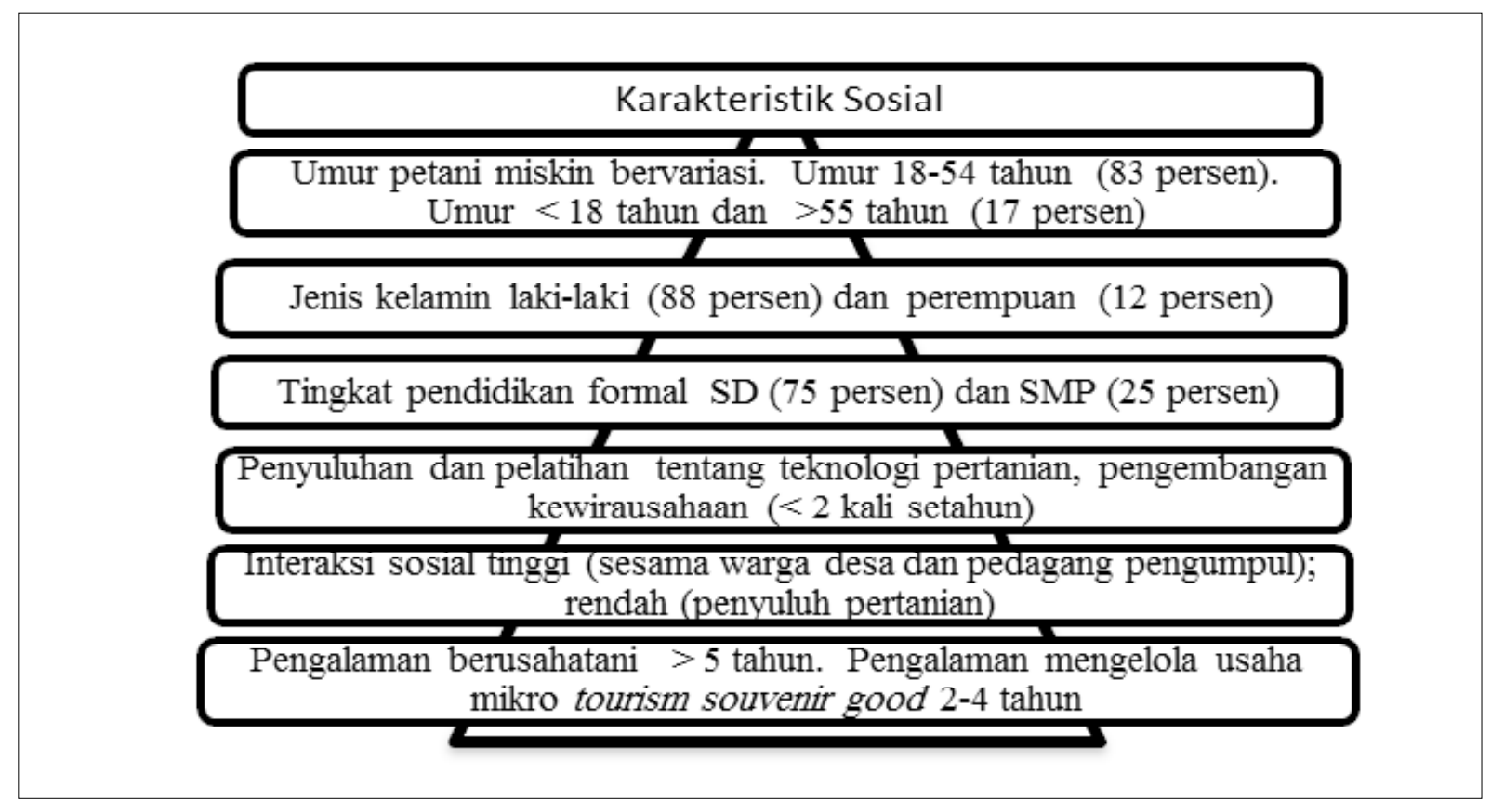

Gambar 1

Karakteristik Sosial Petani Miskin Pengelola Usaha Mikro Tourism Souvenir Goods 
petani miskin di kedua kawasan wisata yang diteliti secara perlahan terselesaikan dengan adanya perolehan pendapatan tambahan dari usaha mikro tourism souvenir goods dari olahan limbah hasil pertanian. Hanya saja, perolehan tambahan pendapatan belum ajeg karena proses produksi bersifat insidental tergantung pesanan (orderan) dari pedagang pengumpul. Pada Gambar 2 teramati karakteristik ekonomi petani pengelola usaha mikro tourism souvenir goods yang diteliti di pedesaan Kawasan Wisata Baturaden dan Cilongok.

Berdasarkan data tersebut terungkap bahwa karakteristik sosial ekonomi petani miskin baik di Kawasan Wisata Baturaden maupun Kawasan Wisata Cilongok mempunyai keragaman potensi kompetensi diri dalam mengelola usaha mikro. Orientasi ekonomi yang dimiliki mayoritas informan masih rendah karena setiap kesempatan produktif dari keberfungsian lingkungannya belum dimanfaatkan secara optimal. Tujuan informan dalam mengelola usaha mikro belum dimaksudkan untuk memperoleh keuntungan maksimal. Niat petani miskin mengelola usaha mikro masih sebatas memperoleh tambahan pendapatan agar lebih mampu menutupi biaya pengeluaran bagi pemenuhan kebutuhan hidup sehari-hari.

Dari keragaman karakteristik sosial ekonomi yang tercantuk pada Gambar 1 dan 2 diketahui ada beberapa beberapa kriteria yang menguatkan potensi petani miskin dalam mengelola usaha mikro tourism souvenir goods. Potensi dan semangat kewirausahaan mendapat dorongan yang kuat dari deretan pengalaman yang dimiliki selama mengelola usaha mikro. Tidak hanya pengalaman ketika memperoleh kenaikan pendapatan yang menjadi kekuatan potensi dan semangat kewirausahaan tetapi pengalaman sewaktu menderita kerugian juga memotivasi petani miskin belajar mengelola usaha mikro agar lebih produktif.

Kegiatan pendidikan tak formal seperti

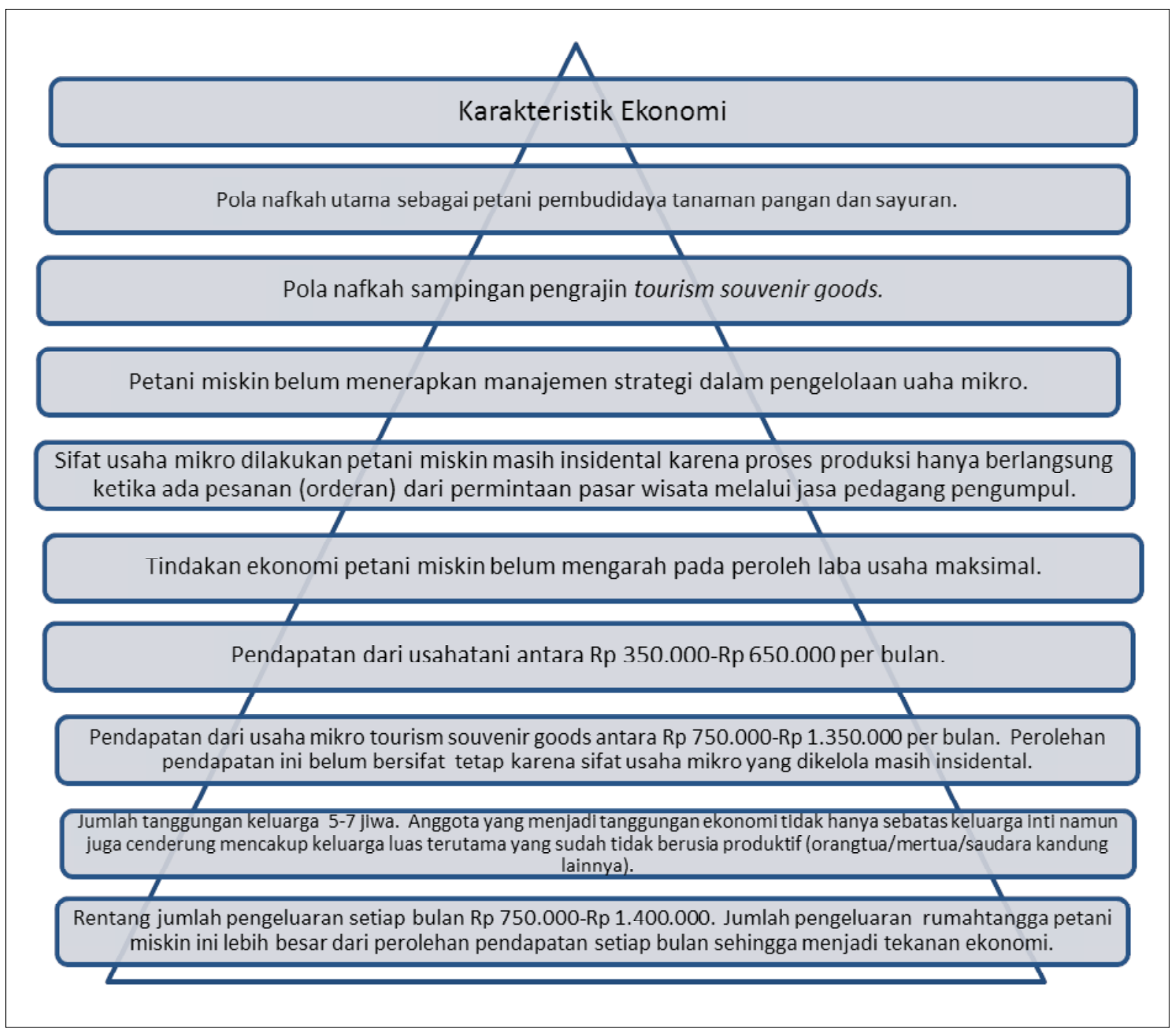

Gambar 2

Karakteristik Ekonomi Petani Miskin Pengelola Usaha Mikro Tourism Souvenir Goods 
penyuluhan, pelatihan, demonstrasi cara dan berbagi pengalaman antar sesama petani termasuk karakteristik sosial yang mendorong dan memotivasi petani miskin meningkatkan potensi dan semangat kewiausahaan. Meski jumlah petani miskin yang mengikuti kegiatan pendidikan tak formal relatif sedikit dengan tingkat intensitas rendah, namun mampu memberi kekuatan bagi upaya pengembangan potensi dan semangat kewirausahaan mengelola usaha mikro tourism suvenir goods dari limbah hasil pertanian.

Tingkat pendidikan tak formal yang rendah mengakibatkan petani pengrajin sulit mengakses informasi inovasi teknologi modifikasi produk dengan aneka desain sesuai trend konsumen di pasar wisata. Kelemahan dalam penguasaan teknologi modifikasi produk menyebabkan mayoritas (75 \%) petani pengrajin baru mampu memproduksi satu sampai tiga desain dan jenis produk tourism souvenir goods dengan motif sederhana dan kurang variatif. Kekuatan beberapa kriteria karakteristik sosial yang diteliti berbeda dalam menentukan potensi dan semangat kewirausahaan petani miskin dalam mengelola usaha mikro baik di Kawasan Wisata Baturaden maupun Cilongok. Perbedaan kekuatan tersebut dapat terlihat pada Gambar 3.

\section{Potensi dan Semangat Kewirausahaan}

Kriteria karakteristik ekonomi petani miskin yang paling mempunyai kekuatan mendorong potensi dan semangat kewirausahaan dalam

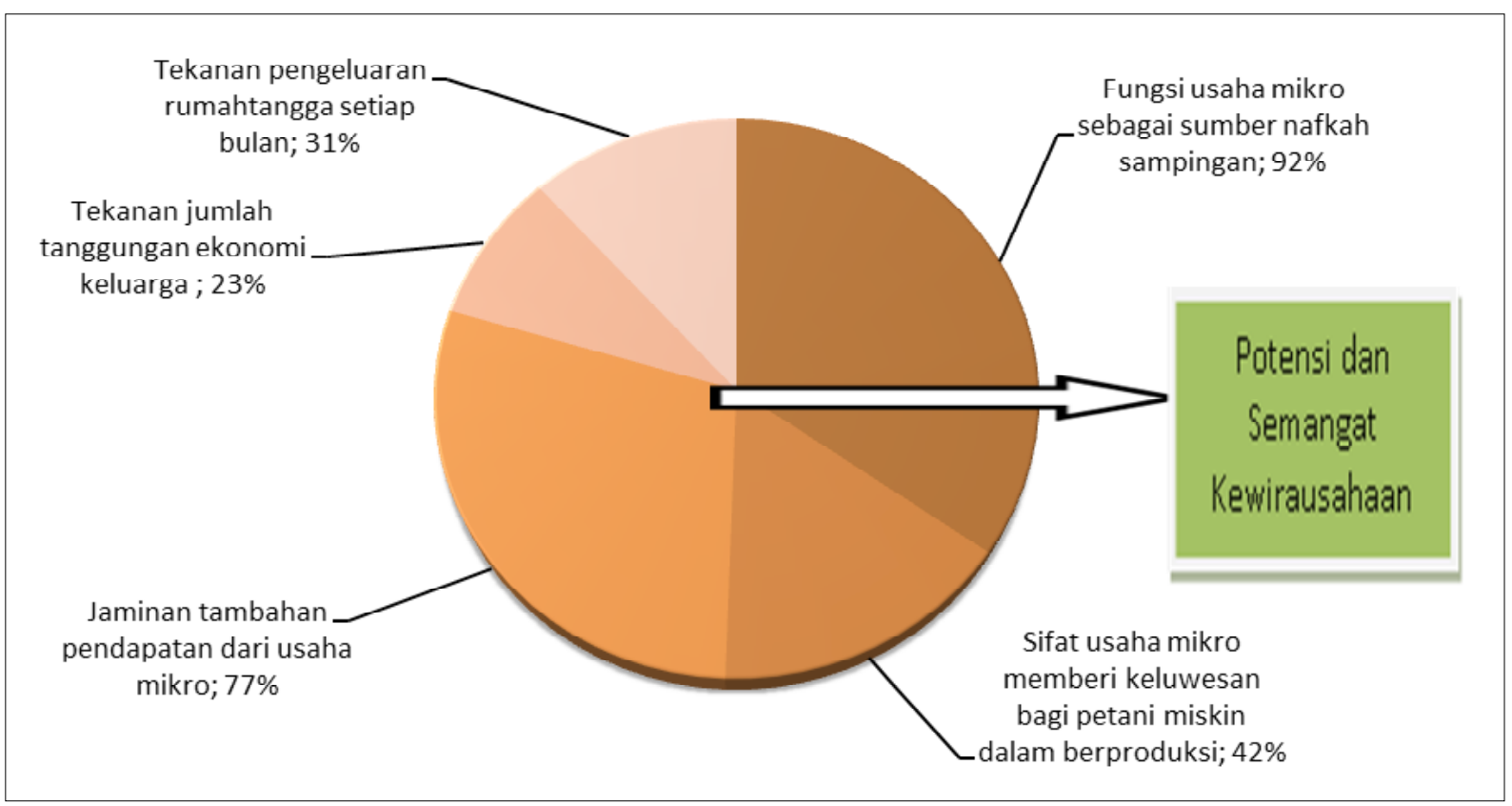

Gambar 3

Tingkat Kekuatan Pengaruh Beberapa Kriteria Karakteristik Sosial Petani Miskin

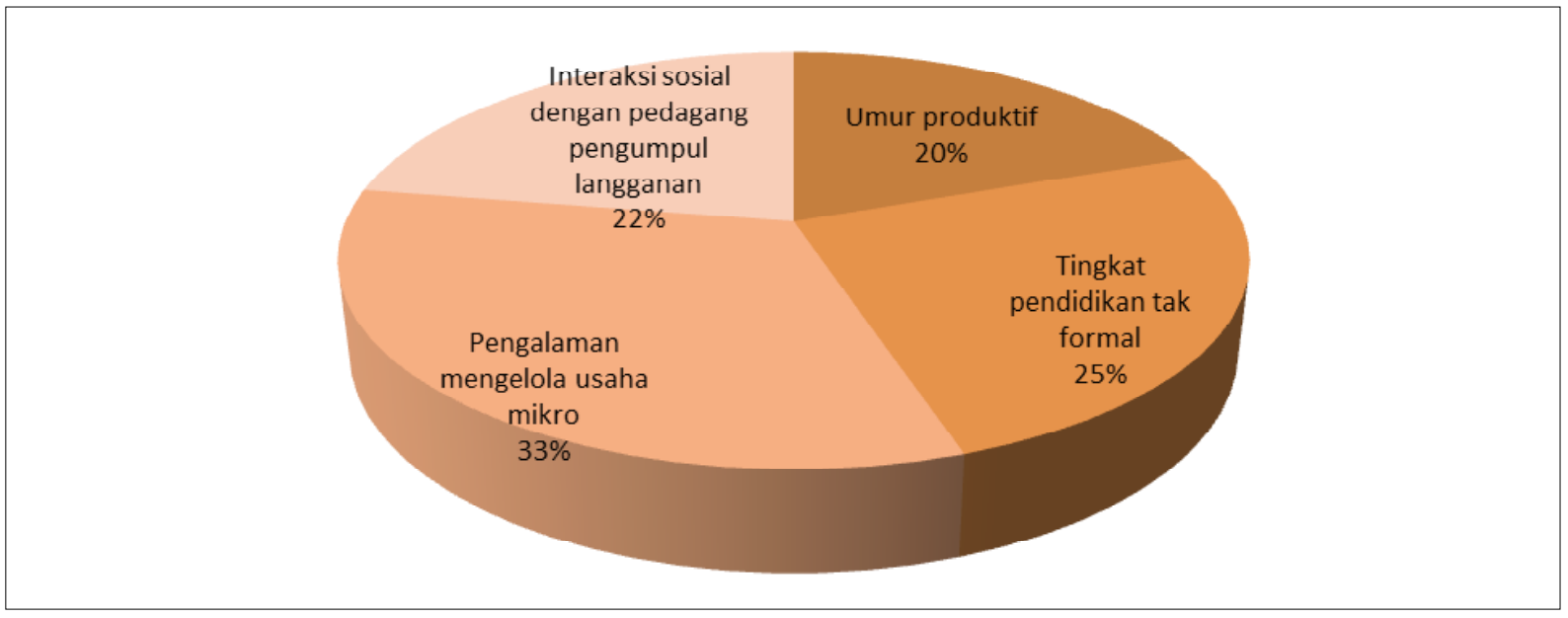


mengelola usaha mikro ialah fungsi usaha mikro sebagai sumber nafkah pendapatan sampingan. Mayoritas petani miskin mengakui ada rasa jaminan keamanan sumber pendapatan tambahan ketika mulai mengelola usaha mikro tourism souvenir goods meski sistem pembayaran produk biasanya berlangsung secara tidak kontan.

Bagi petani miskin ternyata sifat usaha mikro yang masih insidental memberi suatu warna bagi keluwesan dan kelonggaran waktu dalam pengumpulan berbagai jenis bahan baku dari lingkungan sekitar desa. Ketika ada pesanan produk dari pedagang pengumpul yang menjadi langganan barulah petani miskin mulai melakukan proses produksi. Kriteria lain dari karakteristik ekonomi yang mendorong dan memotivasi petani miskin mengelola usaha mikro ialah tekanan pengeluaran rumahtangga yang selalu lebih besar dari penerimaan pendapatan setiap bulan. Jumlah pengeluaran yang seringkali menimbulkan keterdesakan ekonomi bagi keluarga petani miskin untuk mau tidak mau menambah jumlah pinjaman di warung/ pedagang pengumpul erat kaitannya dengan beban tanggungan ekonomi yang relatif tinggi. Informasi tentang kriteria karakteristik sosial yang memiliki kekuatan pengaruh terhadap potensi dan semangat kewirausahaan petani miskin dalam mengelola usaha mikro terinci pada Gambar 4.

Kondisi karakteristik sosial ekonomi pada petani pengrajin tourism souvenir goods di Baturaden dan Cilongok memberi pengaruh yang kuat terhadap pengembangan produktivitas, kreativitas dan kemandirian dalam mengelola usaha mikro. Realitas sosial ini tidak jauh berbeda dengan hasil penelitian yang dilakukan oleh Maris, et all., (2013), yang menemukan beberapa karakteristik sosial ekonomi petani memang mempunyai pengaruh signifikan terhadap tingkat adopsi teknologi pengendalian hama terpadu dalam pengelolaan usahatani tanaman pangan di Desa Metuk, Kecamatan Mojosongo, Kabupaten Boyolali. Beberapa karakteristik sosial ekonomi bahkan mampu berfungsi menguatkan adopsi teknologi pengendalian hama terpadu pasca Sekolah Lapang Pengendalian Hama Terpadu ialah: pendidikan tak formal, pengalaman petani mengelola usahatani dan keaktifan keanggotaan petani (Maris, et all., 2013). Demikian juga yang fakta sosial ditemukan dari hasil penelitian Malta (2011), yang menunjukkan bahwa kompetensi merupakan salah satu karakteristik sosial penentu perilaku dan kinerja dalam mengelola ragam usahatani di pedesaan. Oleh karena itu, pada setiap upaya pemberdayaan termasuk pengembangan usaha mikro tourism souvenir goods perlu terlebih dahulu dilakukan identifikasi dan pengenalan karakteristik sosial ekonomi petani miskin baik di pedesaan Kawasan Wisata Baturaden maupun Kawasan Wisata Cilongok.

\section{Profil Usaha Mikro}

Profil usaha mikro tourism souvenir goods yang dikelola petani miskin di kedua lokasi penelitian memiliki beberapa persamaan dan perbedaan dalam berbagai aspek ditinjau dari: bahan baku, jumlah modal, sumber modal, desain produk, volume produk, teknologi pengolahan,

\section{Tabel 1}

Profil Usaha Mikro dengan Beberapa Kesamaan Ciri

\begin{tabular}{|c|c|}
\hline Profil & Keterangan \\
\hline Bahan baku & $\begin{array}{l}\text { Aneka jenis limbah hasil pertanian (limbah gergajian/potongan industri kerajinan kayu/bambu, } \\
\text { tempurung kelapa, biji//ranting pohon yang mengering, limbah kulit hewan sapi/kambing). }\end{array}$ \\
\hline Tenaga kerja & $\begin{array}{l}\text { Dari kalangan anggota keluarga sendiri. Bila pesanan sedang banyak ditambah tenaga kerja dari } \\
\text { kalangan tetangga/kerabat desa. Jumlah tenaga kerja 3-4 orang setiap proses produksi. }\end{array}$ \\
\hline Sumber modal & Milik sendiri dan pinjaman dari: pedagang pengumpul, simpan pinjam RT/RW dan bank plecit desa. \\
\hline $\begin{array}{l}\text { Desain dan motif } \\
\text { produk }\end{array}$ & $\begin{array}{l}\text { Tidak variatif. Baru memproduksi satu sampai tiga jenis produk tourism souvenir goods. Misalnya: } \\
\text { asbak, celengan dan gasing dari limbah industri kerajinan bambu. Bingkai foto, gantungan kunci } \\
\text { dan vas bunga dari limbah industri kerajinan kayu. }\end{array}$ \\
\hline Sifat usaha & Proses produksi bersifat insidental tergantung pesanan dari pedagang pengumpul langganan. \\
\hline Sistem penjualan & Setor produk secara borongan (kulakan) ke pedagang pengumpul sesuai jumlah pesanan. \\
\hline Sistem pembayaran & $\begin{array}{l}\text { Langsung tunai, cicilan (ngebon) dengan sistem pelunasan saat pengambilan pesanan produk } \\
\text { berikutnya. }\end{array}$ \\
\hline $\begin{array}{l}\text { Penetapan harga } \\
\text { produk }\end{array}$ & Pedagang pengumpul \\
\hline
\end{tabular}


sistem penjualan, sistem pembayaran dan jangkauan pasar. Pada Tabel 1 teramati profil usaha mikro petani miskin di pedesaan Kawasan Wisata Baturaden dan Kawasan Wisata Cilongok dengan beberapa kesamaan ciri.

Profil usaha mikro yang dikelola petani miskin di kedua kawasan wisata yang diteliti juga menunjukkan beberapa perbedaan ciri. Pada Tabel 2 tercantum profil usaha mikro yang dikelola petani miskin di pedesaan Kawasan Wisata Baturaden dan Kawasan Wisata Cilongok ditinjau dari perbedaan beberapa ciri.

Profil usaha mikro yang dikelola petani miskin menunjukkan eksistensi yang lemah dalam hal yang terkait khusus dengan kemandirian, kemampuan kewirausahaan dan adopsi teknologi modifikasi produk. Selama ini, petani miskin baru memiliki potensi dan semangat kewirausahaan. Sementara, kemampuan masih kurang optimal dalam memanfaatkan berbagai kesempatan bisnis tourism souvenir goods. Pengembangan kemandirian dan kemampuan kewirausahaan serta adopsi teknologi pada petani miskin tidak dapat terlepas dari respon sekaligus dukungan sumberdaya lokal di sekitar lingkungan desa. Hal ini sesuai dengan hasil penelitian Indratno dan Agustina (2005), yang mengemukakan bahwa kemampuan masyarakat desa termasuk petani miskin mengembangkan ekonomi lokal tergantung pada kesiapan dalam proses produksi, pembentukan modal dan peningkatan kualitas sumberdaya manusia.

Tabel 2

Profil Usaha Mikro dengan Beberapa Perbedaan Ciri

\begin{tabular}{|c|c|c|}
\hline \multirow[t]{2}{*}{ Profil } & \multicolumn{2}{|c|}{ Pedesaan } \\
\hline & Kawasan Wisata Baturaden & Kawasan Wisata Cilongok \\
\hline Jumlah modal & Rata-rata Rp 650.000-Rp 1.000.000. & Rata-rata Rp 450.000-Rp 650.000. \\
\hline Volume produk & Rata-rata $>25$ buah per hari kerja & Rata-rata $<25$ buah per hari kerja \\
\hline $\begin{array}{l}\text { Teknologi } \\
\text { pengolahan }\end{array}$ & $\begin{array}{l}\text { Sudah ada sebagian ( } 25 \%) \text { dari petani } \\
\text { miskin yang memggunakan teknologi } \\
\text { semi manual pada pra produksi dan } \\
\text { proses produksi. } \\
\text { Hanya } 10 \% \text { petani miskin yang } \\
\text { melakukan tahap finishing dan } \\
\text { pengemasan. }\end{array}$ & $\begin{array}{l}\text { Semua petani miskin menggunakan } \\
\text { teknologi dengan cara manual baik } \\
\text { pada tahap pra produksi dan proses } \\
\text { produksi. Jarang sekali petani } \\
\text { miskin melakukan tahap finishing } \\
\text { dan pengemasan. }\end{array}$ \\
\hline Jangkauan pasar & $\begin{array}{l}\text { Kawasan Wisata Banyumas dan luar } \\
\text { Banyumas }\end{array}$ & Kawasan Wisata Banyumas \\
\hline
\end{tabular}

Tabel 3

Ragam Faktor Penyebab Sensitivitas Informan Lemah dalam Pengelolaan Usaha Mikro

\begin{tabular}{|c|c|c|c|}
\hline \multirow[t]{2}{*}{ No. } & \multirow[t]{2}{*}{ Ragam Faktor Penyebab } & \multicolumn{2}{|c|}{ Sifat } \\
\hline & & Internal & Eksternal \\
\hline 1. & $\begin{array}{l}\text { Aksesibilitas rendah terhadap informasi aneka produk sesuai trend } \\
\text { pasar wisata }\end{array}$ & $\sqrt{ }$ & \\
\hline 2. & $\begin{array}{l}\text { Kreativitas dalam penentuan jenis, bentuk, desain dan motif produk } \\
\text { rendah }\end{array}$ & $\sqrt{ }$ & \\
\hline 3. & $\begin{array}{l}\text { Pengetahuan dan ketrampilan informan rendah dalam proses } \\
\text { pengolahan produk berkualitas sesuai trend pasar wisata }\end{array}$ & $\sqrt{ }$ & \\
\hline 4. & $\begin{array}{l}\text { Fasilitas pelayanan informasi permintaan produk sesuai trend pasar } \\
\text { wisata langka }\end{array}$ & & $\sqrt{ }$ \\
\hline 5. & $\begin{array}{l}\text { Penentuan jenis dan bentuk produk (desain dan motif) cenderung } \\
\text { didominasi pedagang pengumpul }\end{array}$ & & $\sqrt{ }$ \\
\hline 6. & Jaringan kerjasama dengan pasar wisata lemah & $\sqrt{ }$ & $\sqrt{ }$ \\
\hline 7. & Bengkel produksi belum memadai & $\sqrt{ }$ & \\
\hline 8. & Proses pengolahan produk cenderung tanpa melalui tahap finishing & $\sqrt{ }$ & \\
\hline
\end{tabular}

Sumber: Diolah dari data primer Tahun 2011 


\section{Pengelolaan Usaha Mikro Tourism Sou - venir Goods}

Di samping kemandirian, kemampuan kewirausahaan dan adopsi teknologi modifikasi produk ternyata unsur lain yang turut menentukan peningkatan produktivitas petani miskin dalam mengelola usaha mikro tourism souvenir goods di Baturaden dan Cilongok adalah sensitivitas dalam mengidentifikasi produk sesuai trend permintaan konsumen di pasar wisata. Mayoritas (88\%) informan masih memiliki sensitivitas yang lemah dalam menyesuaikan jenis, bentuk, desain dan motif produk dengan trend pasar wisata. Kelemahan informan dalam sensitivitas usaha mikro disebabkan beberapa faktor yang bersifat internal dan eksternal.

Faktor internal bersumber dari lingkungan pribadi dan keluarga informan. Sementara, cakupan faktor eksternal berasal dari sistem sosial di luar lingkungan pribadi dan keluarga. Penjelasan beberapa faktor penyebab kelemahan sensitivitas usaha mikro petani miskin baik yang bersifat internal maupun eksternal di Kawasan
Wisata Baturaden dan Cilongok tercantum pada Tabel 3.

Meskipun masih memiliki sensitivitas yang lemah dalam mengelola usaha mikro namun petani miskin merasa yakin tetap mampu bertahan melanjutkan produksi karena alasan permintaan pasar wisata terhadap produk tourism souvenir goods terus meningkat secara perlahan dari tahun ke tahun. Selain dipasarkan di beberapa lokasi kawasan wisata wilayah Banyumas, jangkauan pemasaran souvenir yang dihasilkan petani miskin dari Kawasan Wisata Baturaden dan Cilongok juga menyebar di berbagai objek wisata luar Banyumas seperti: Yogyakarta, Bandung, Semarang, Purbalingga, Tegal, Kebumen, Pekalongan, Cilacap, Pangandaran dan lain-lain. Sesuatu realitas sosial yang menarik diperhatikan, ketika menyadari souvenir yang dibawa ke luar wilayah Banyumas suatu waktu kembali lagi dipasarkan ke Kawasan Wisata Baturaden setelah mengalami proses finishing di tempat lain oleh pedagang pengumpul. Peningkatan permintaan yang datang melalui pedagang pelanggan terhadap beberapa jenis dan

\section{Tabel 4 \\ Peningkatan Transaksi Penjualan Aneka Produk Tourism Souvenir Goods antara Tahun 2010-2011}

\begin{tabular}{|l|c|c|c|c||}
\hline \multicolumn{1}{|c|}{ Jenis Tourism Souvenir Goods } & \multicolumn{2}{c|}{$\begin{array}{c}\text { Jumlah Penjualan } \\
\text { (Buah) }\end{array}$} & \multicolumn{2}{c|}{ Tingkat Kenaikan } \\
& Tahun 2010 & Tahun 2011 & $\begin{array}{c}\text { Jumlah } \\
\text { (Buah) }\end{array}$ & $\begin{array}{c}\% \text { tase } \\
\text { (\%) }\end{array}$ \\
\hline - Aneka Miniatur Kendaraan dari Kayu & & & 125 & 17 \\
- Aneka Gantungan Kunci dari Kayu dan Tempurung & 2100 & 2400 & 300 & 14 \\
Kelapa & & & & \\
- Celengan Bunga dari Tempurung Kelapa dan Bunga & 1525 & 1800 & 275 & 18 \\
Pinus & & & & \\
- Celengan Gantung dari Tempurung Kelapa & 750 & 825 & 75 & 10 \\
- Wayang Kulit dari Kulit Hewan Sapi & 300 & 400 & 100 & 33 \\
- Seruling Jawa (5 lubang) dari Bambu Wuluh & 2500 & 2700 & 200 & 8 \\
- Vas Bunga Meja dari Irisan Bambu Tutul & 800 & 1020 & 220 & 28 \\
- Seruling Nasional (6 lubang) dari Bambu Wuluh & 2250 & 2500 & 250 & 11 \\
- Senjata Hiasan Ukiran Bawor dari Kayu & 750 & 950 & 200 & 27 \\
- Kipas dari Irisan Bambu Wuluh & 2700 & 2950 & 250 & 9 \\
- Vas Bunga Gantung dari Bambu dan Bunga Pinus & 650 & 800 & 150 & 23 \\
- Gangsing Puteran dari Bambu & & & & \\
- Figura Photo (Gantung) dari Kayu Albazia dan Bunga & 3250 & 3600 & 350 & 11 \\
Pinus & 1350 & 1575 & 225 & 17 \\
- Wayangan Mini dari Kulit Ternak & 850 & 1100 & 250 & 29 \\
- Kututan dari Bambu Wuluh & 2750 & 3200 & 450 & 16 \\
- Asbak dari Bambu TutulTempurung Kelapa & 1600 & 2000 & 400 & 25 \\
- Aneka Patung dari Sisa Kayu Gergajian & 775 & 1150 & 375 & 48 \\
- Gangsing Puteran dari Bambu Tutul & 2400 & 2650 & 250 & 10 \\
- Aneka Bentuk Anyaman dari Bambu & 3750 & 4200 & 450 & 12 \\
\hline
\end{tabular}

Sumber: Diolah dari data primer Tahun 2011 
bentuk tourism souvenir goods di Kawasan Wisata Baturaden dan Cilongok pada selang waktu 20102011 teramati pada Tabel 4.

Berbagai produk yang mengalami kenaikan penjualan seperti terlihat pada Tabel 4 menjadi pilihan bagi informan dalam melanjutkan usaha mikro. Menurut penjelasan mayoritas informan (92\%) diketahui bahwa keputusan yang diambil dalam setiap kali melakukan proses produksi ialah menetapkan jenis dan bentuk produk tourism souvenir goods tertentu yang sudah memiliki jaminan pasar. Setiap informan mempunyai keahlian dalam menghasilkan satu sampai tiga jenis produk dengan bentuk, desain dan motif yang tidak berbeda dari waktu ke waktu. Teknik pemasaran yang dilakukan informan melalui pemanfaatan jasa pedagang pengumpul. Para informan yang merintis usaha mikro tourism souvenir goods jarang sekali mendapat penawaran dari pihak lain secara langsung misal konsumen perorangan atau kelompok wisatawan.

Tingkat harga produk souvenir yang dihasilkan petani miskin di kedua lokasi penelitian jauh dibawah standar harga yang berlaku di pasar wisata. Jika terjadi kenaikan harga produk maka keputusan tersebut selalu berasal dari pihak pedagang pengumpul yang menjadi pelanggan. Petani pengrajin belum merasa perlu turut serta dalam penetapan harga produk karena yang terpenting baginya ialah segera dapat menjual produk tanpa melalui proses tawar menawar. Kondisi ini menunjukkan posisi tawar petani miskin masih lemah karena penetapan harga produk berada pada satu pihak yakni pedagang pengumpul. Petani miskin enggan bernegoisasi tentang ketetapan harga karena merasa ewuh

Tabel 5

Kenaikan Harga Berbagai Jenis Tourism Souvenir Goods antara Tahun 2010-2011

\begin{tabular}{|c|c|c|c|c|}
\hline \multirow[t]{2}{*}{ Jenis Tourism Souvenir Goods } & \multicolumn{2}{|c|}{$\begin{array}{l}\text { Tingkat Harga } \\
\text { (Rp/buah) }\end{array}$} & \multicolumn{2}{|c|}{$\begin{array}{c}\text { Tingkat } \\
\text { Kenaikan Harga }\end{array}$} \\
\hline & Tahun 2010 & Tahun 2011 & $\begin{array}{c}\text { Kenaikan } \\
\text { Harga } \\
\text { (Rp/Buah) }\end{array}$ & $\begin{array}{c}\% \text { tase } \\
(\%)\end{array}$ \\
\hline - $\quad$ Aneka Miniatur Kendaraan dari Kayu & $25.000-34.000$ & $26.000-35.000$ & 1.000 & 3 \\
\hline $\begin{array}{l}\text { - Aneka Gantungan Kunci dari Kayu dan } \\
\text { Tempurung Kelapa }\end{array}$ & $1.000-3.000$ & $1.250-3.250$ & 250 & 13 \\
\hline $\begin{array}{l}\text { - Celengan Bunga dari Tempurung Kelapa dan } \\
\text { Bunga Pinus }\end{array}$ & 4.000 & 4500 & 500 & 13 \\
\hline - Celengan Gantung dari Tempurung Kelapa & 5.000 & 5.250 & 250 & 5 \\
\hline - Wayang Kulit dari Kulit Hewan Sapi & 35.000 & 37.500 & 2.500 & 7 \\
\hline - Seruling Jawa (5 lubang) dari Bambu Wuluh & 4.000 & 4.500 & 500 & 13 \\
\hline - Vas Bunga Meja dari Irisan Bambu Tutul & 6.250 & 6.500 & 250 & 4 \\
\hline $\begin{array}{l}\text { - Seruling Nasional (enam lubang) dari Bambu } \\
\text { Wuluh }\end{array}$ & 5.300 & 5.500 & 200 & 4 \\
\hline - Senjata Hiasan Ukiran Bawor dari Kayu & 25.000 & 27.500 & 2.500 & 10 \\
\hline - Kipas dari Irisan Bambu Wuluh & 3.000 & 3.750 & 750 & 25 \\
\hline $\begin{array}{l}\text { - Vas Bunga Gantung dari Bambu dan Bunga } \\
\text { Pinus }\end{array}$ & 6.250 & 6.500 & 250 & 4 \\
\hline - Gangsing Puteran dari Bambu & 4.250 & 4.750 & 500 & 12 \\
\hline $\begin{array}{l}\text { - Figura Photo (Gantung) dari Kayu Albazia dan } \\
\text { Bunga Pinus }\end{array}$ & 5.500 & 5.750 & 250 & 5 \\
\hline - Wayangan Mini dari Kulit Ternak & 12.000 & 12.500 & 500 & 4 \\
\hline - Kututan dari Bambu Wuluh & 5.000 & 5.200 & 200 & 4 \\
\hline - $\quad$ Asbak dari Bambu TutulTempurung Kelapa & 3.200 & 3.600 & 400 & 13 \\
\hline - $\quad$ Aneka Patung dari Sisa Kayu Gergajian & $12.000-32.000$ & $15.000-35.000$ & 3.000 & 14 \\
\hline - Gangsing Puteran dari Bambu Tutul & 5.200 & 5.700 & 500 & 10 \\
\hline - Aneka Bentuk Anyaman dari Bambu Wuluh & $6.500-21.000$ & $8.000-22.500$ & 1.500 & 11 \\
\hline
\end{tabular}

Sumber: Diolah dari data primer Tahun 2011 
pekewuh atau sungkan dengan pedagang pelanggan, yang telah bertahun-tahun mau memborong produk olahannya dalam bentuk apa adanya tanpa pernah mempersoalkan masalah kualitas. Para informan khawatir bila memersoalkan harga produk maka menimbulkan kondisi kurang kondusif pada pedagang pelanggan misal menjadi tersinggung hingga pada akhirnya tidak mau lagi membeli produk tourism souvenir goods. Pada Tabel 5 terlihat kenaikan harga berbagai jenis tourism souvenir goods.

Berdasarkan informasi yang tertera pada Tabel 5 diketahui kenaikan harga produk yang dihasilkan para informan terjadi secara perlahan antara 3-25\%. Dengan rentang harga yang demikian, pesanan produk tidak datang setiap hari. Akan tetapi, pesanan berlangsung antara sekali dalam seminggu sampai sekali dalam dua bulan. Dalam setahun pemesanan terjadi enam sampai dua puluh empat kali. Sistem pemesanan yang demikian, membuat petani miskin agak santai dalam mengelola usaha mikro tourism souvenir goods.

Petani miskin mengumpulkan bahan baku berupa ragam jenis limbah hasil pertanian dari lingkungan desa setempat. Pekerjaan sebagai pengrajin tourism souvenir goods merupakan pola nafkah sampingan bagi informan karena dilakukan terutama saat kegiatan bertani sedang senggang atau sewaktu sore/malam hari pulang dari sawah/ kebun. Tak jarang, semua anggota keluarga ikut terlibat dalam kegiatan proses produksi. Jenis pekerjaan ini disenangi karena tidak mengikat waktu. Bahan baku yang dibutuhkan untuk membuat berbagai jenis souvenir tidak sulit karena dapat dikumpulkan sambil berangkat ke sawah/ kebun. Para informan sering menyempatkan diri mengumpulkan ragam jenis bahan baku berbagai jenis limbah hasil pertanian yang berserakan di sekeliling lahan pertaniannya. Beberapa bahan baku didapatkan juga dari limbah usaha pertanian yang ada di lingkungan desa sekitar. Pengumpulan bahan baku limbah hasil pertanian dikerjakan tanpa menunggu pesanan souvenir dari pedagang pelanggan. Semua bahan baku dikumpulkan di dapur rumah tinggal. Saat matahari terik, dijemur untuk pengeringan agar lebih awet. Sebelum dijemur, bahan baku dicuci bersih di sumur. Petani tak perlu mengeluarkan biaya pembelian bahan baku.

Biaya produksi pengolahan limbah hasil pertanian menjadi aneka souvenir setengah jadi dapat menjadi irit. Dengan modal usaha yang minim, para informan bisa bertahan meneruskan pengelolaan usaha mikro dengan menggunakan peralatan kerja atau perkakas yang terbatas. Kadang kala perkakas aus juga terus dimanfaatkan setelah terlebih dahulu diperbaiki oleh informan. Beberapa bahan pelengkap dan alat kerja yang dipakai untuk kepentingan proses produksi souvenir mencakup: lem perekat, amplas dan mata kikir. Bahan dan alat diperoleh dengan cara menitip beli kepada warga tetangga, yang kebetulan berangkat untuk suatu kepentingan ke Kota Purwokerto.

Petani miskin memiliki kemampuan bertahan mengelola usaha mikro tourism souvenir goods di Kawasan Wisata Baturaden dan Cilongok karena dorongan kemanfaatannya baik dari dimensi ekonomi, sosial budaya dan lingkungan. Berdasarkan penjelasan para informan, beberapa kemanfaatan yang dimaksud tercantum secara rinci pada Tabel 6.

Beberapa kemanfaatan usaha mikro seperti teramati pada Tabel 6 memberikan kesempatan bagi para informan dalam meningkatkan ekonomi

Tabel 6

Ragam Kemanfaatan Usaha Mikro Tourism Souvenir Goods bagi Rumahtangga Informan

\begin{tabular}{|l|c|c|c|}
\hline \multicolumn{1}{|c|}{ Ragam Kemanfaatan } & \multicolumn{2}{c|}{ Dimensi } \\
\cline { 2 - 4 } & Ekonomi & $\begin{array}{c}\text { Sosial } \\
\text { Budaya }\end{array}$ & Lingkungan \\
\hline Sumber tambahan pendapatan rumahtangga & $\sqrt{ }$ & & \\
\hline Pola nafkah sampingan & $\sqrt{ }$ & \\
\hline $\begin{array}{l}\text { Penyerap tenaga kerja dari anggota keluarga inti } \\
\text { dan kerabat serta lingkungan ketetanggaan } \\
\text { terdekat }\end{array}$ & & $\sqrt{ }$ & $\sqrt{ }$ \\
\hline $\begin{array}{l}\text { Pereduksi polutan pencemar lingkungan karena } \\
\text { memanfaatkan limbah hasil pertanian sebagai } \\
\text { bahan baku }\end{array}$ & & $\sqrt{ }$ & \\
\hline $\begin{array}{l}\text { Wadah interaksi sosial petani pengrajin dengan } \\
\text { pedagang pengumpul }\end{array}$ & & & \\
\hline
\end{tabular}

Sumber: Diolah dari data primer Tahun 2011 
rumahtangga petani miskin baik di Kawasan Wisata Baturaden maupun Cilongok. Realisasi beberapa kemanfaatan usaha mikro tourism souvenir goods dari olahan limbah hasil pertanian juga memotivasi perilaku petani miskin dalam upaya pengembangan diversifikasi nafkah produktif di pedesaan (Dumasari dan Watemin, 2008).

\section{Simpulan dan Saran}

Petani miskin memiliki karakteristik sosial ekonomi tertentu dalam mengelola usaha mikro tourism suvenir goods di pedesaan Kawasan Wisata Baturaden dan Kawasan Wisata Cilongok. Beberapa kriteria yang mencerminkan karakteristik sosial ekonomi petani miskin ternyata mempunyai kekuatan pengaruh mendorong dan memotivasi potensi dan semangat petani miskin dalam mengelola usaha mikro.

Kriteria karakteristik sosial yang memberi dorongan dan motivasi ialah: pengalaman mengelola usaha mikro, pendidikan tak formal, nteraksi dengan pedagang pengumpul langganan dan umur produktif. Adapun kriteria karakteristik ekonomi yang memberi dorongan dan motivasi adalah: fungsi usaha mikro sebagai sumber nafkah sampingan, jaminan tambahan pendapatan dari usaha mikro, sifat usaha mikro memberi keluwesan bagi petani miskin dalam berproduksi, tekanan pengeluaran rumahtangga setiap bulan dan tekanan jumlah tanggungan ekonomi keluarga.

Profil usaha mikro tourism souvenir goods yang dikelola petani miskin menunjukkan adanya persamaan dan perbedaan ciri. Persamaan beberapa ciri terungkap dari bahan baku, tenaga kerja, sumber modal, desain produk, sifat usaha, sistem penjualan dan sistem pembayaran. Sebaliknya, perbedaan beberapa ciri teramati dari: jumlah modal, volume produk, teknologi pengolahan dan jangkauan pasar.

Penyelesaian permasalahan dari kelemahan karakteristik sosial ekonomi petani miskin pengelola usaha mikro tourism souvenir goods dalam kemandirian, kemampuan kewirausahaan dan adopsi teknologi modifikasi produk perlu segera dilaksanakan khususnya melalui berbagai kegiatan pendidikan tak formal partisipatif. Beberapa upaya lain yang urgen dilakukan ialah melalui penyediaan fasilitas pelayanan informasi teknologi, modal tambahan, harga dan pasar di level desa. Selain itu, perlu juga mengadakan transfer teknologi dari berbagai pihak yang memiliki keahlian dan ketrampilan mengelola usaha souvenir dari limbah hasil pertanian kepada petani pengrajin guna meningkatkan akses terhadap informasi desain dan jenis produk serta motif yang bervariasi sesuai trend konsumen di pasar wisata.

\section{Daftar Pustaka}

Dumasari, Watemin dan Sumadi Sudrijat. (2007). Pengembangan Model Pemberdayaan Wanita Tani Miskin melalui Pengelolaan Teknologi Modifikasi Produk Limbah Industri Pertanian menjadi Tourism Souvenur Goods Khas Pariwisata Banyumas. Laporan Hasil Penelitian Hibah Bersaing Tahun 2007. DP2M Dikti Depdiknas RI. Fakultas Pertanian. Universitas Muhammadiyah Purwokerto.

Dumasari dan Watemin. (2007). Kajian Gender tentang Trend Pergeseran Kerja dari Pertanian Ke Non Pertanian dan Kontribusinya terhadap Eksistensi Rumahtangga Buruh Tani. Jurnal Siasat. Volume 16 Nomor 2 Oktober 2007.

Dumasari dan Watemin. (2008). Pemberdayaan Petani Miskin melalui Pengembangan Usaha Mikro Tourism Souvenir Goods dari Limbah Pertanian dengan Pemanfaatan Teknologi Modifikasi Produk Ramah Lingkungan. Pemberdayaan Petani Miskin melalui Pengembangan Usaha Mikro Tourism Souvenir Goods dari Limbah Pertanian dengan Pemanfaatan Teknologi Modifikasi Produk Ramah Lingkungan.

Indratno, Imam dan Ina Helena Agustina. (2005). Studi Kemampuan Masyarakat dalam Pengembangan Ekonomi Lokal sebagai Upaya Pengentasan Kemiskinan (Studi Kasus Desa Tegalurung, Kecamatan Legon Kulon, Kabupaten Subang). Jurnal Mimbar Volume XXI Nomor 3 Edisi Juli-September 2005. Hal 427-428. Bandung: P2U LPPM Unisba.

Malta. (2011). Faktor-Faktor yang Berhubungan dengan Kinerja Petani Jagung di Lahan Gambut. Jurnal Mimbar Volume XXVII Nomor 1 Edisi Juni 2011. Hal 70-71.

Maris, Paramesti, Sapja Anantanyu dan Suprapto. (2013). Hubungan antara Karakteristik Sosial Ekonomi Petani dengan Tingkat Adopsi Teknologi PHT Pasca SLPHT Padi di Desa Metuk, Kecamatan Mojosongo, Kabupaten Boyolali. E-Jurnal Agrista Volume 1 Nomor 1 Tahun 2013. Hal 8-10.

Midgley, James. (1995). Social Welfare in Global Context. Sage Publication. London and New Delhi.

Miles, M. B., and A. M., Huberman. (1991). Designing Qualitative Research. Mac Graw Hill Company. New York.

Spencer, L. M., and Spencer A. M., (1993). Competence at Work. Models for Superior Performance. John Wiley and Son, Inc. 


\section{Formulir Berlangganan MIMBAR}

Saya ingin berlangganan untuk (lingkari yang diperlukan):

Edisi sekarang dan sebelumnya

Volume 28, Nomor 1 - 2012

Volume 28, Nomor 2 - 2012

Volume 29, Nomor 1 - 2013

Volume 29, Nomor 2 - 2013

Edisi selanjutnya,

>> Selama satu tahun

>> Selama dua tahun

>> Selama tiga tahun

\section{Jumlah eksemplar}

eksemplar.

eksemplar.

eksemplar.

eksemplar.

\section{Jumlah eksemplar}

eksemplar.

eksemplar.

eksemplar.

\section{Pembayaran dilakukan melalui:}

m Transfer (Fotokopi bukti transfer dilampirkan bersama Formulir ini).

m Rekening: Bank BNI No. 0302265182 Cabang Dago (Perguruan Tinggi) atas nama: Dadi Ahmadi

\section{Data Pelanggan}

Nama

\section{Alamat}

\section{Telp/HP}

\section{E-mail}

\section{Keterangan:}

Harga langganan untuk Volume 29 No.1 dan Sebelumnya per eksemplar adalah Rp 80.000,00. Untuk edisi 29 No.2 dan seterusnya adalah 100.000,- (belum termasuk ongkos kirim).

Cara Berlangganan Bila telah diisi lengkap, mohon Formulir ini dimasukkan amplop beserta bukti pembayaran dan dikirimkan ke alamat: Jurnal Sosial dan Pembangunan MIMBAR. Jl. Tamansari No. 20, Lantai 4. Bandung 40116, Telp. (022) 4203368, Pes. 155 Faks. (022) 4263895. surel: mimbar@unisba.ac.id atau mimbarunisba@gmail.com. Permohonan langganan dapat juga dilakukan via pos, e-mail, atau telepon. 